\title{
Non-Tuberculous Mycobacterial Infection Localized in Small Intestine Developing after Allogeneic Bone Marrow Transplantation
}

\author{
Rie Yamazaki ${ }^{1,2}$, Takehiko Mori ${ }^{1}$, Tomonori Nakazato ${ }^{1}$, Yoshinobu Aisa ${ }^{1}$, Hiroyuki Imaeda $^{3}$, \\ Tadakazu Hisamatsu ${ }^{3}$, Toshifumi Hibi $^{3}$ and Shinichiro Okamoto ${ }^{1}$
}

\begin{abstract}
A 33-year-old man with myelodysplastic/myeloproliferative disease underwent allogeneic bone marrow transplantation. Around day 80 post-transplant, he complained of abdominal pain and diarrhea. Colonoscopy and esophagogastroduodenoscopy findings were unremarkable. Double-balloon enteroscopy revealed atrophic villi and mild erosions localized in the small intestine. Histological examination revealed marked proliferation of histiocytes with numerous acid-fast bacilli in their cytoplasm. The specific polymerase chain reaction for Mycobacterium tuberculosis was negative, and a diagnosis of intestinal non-tuberculous mycobacteria (NTM) was made. Physicians should recognize that NTM infection is one of the gastrointestinal infectious complications in immunocompromised patients such as bone marrow transplant recipients, and could localize in the small intestine.
\end{abstract}

Key words: non-tuberculous mycobacteria, small intestine, allogeneic hematopoietic stem cell transplantation, double-balloon enteroscopy

(Inter Med 49: 1191-1193, 2010)

(DOI: 10.2169/internalmedicine.49.3288)

\section{Introduction}

Non-tuberculous mycobacteria (NTM) have been reported to cause pneumonia, lymphadenitis, skin and soft tissue infection, and central venous catheter infection (1). Disseminated NTM infection has been reported in non-human immunodeficiency virus-associated immunocompromised hosts (2). NTM infection after hematopoietic stem cell transplantation (HSCT) is quite rare $(3,4)$, and intestinal NTM infection is even rarer; only one case has been reported after HSCT (5). Here, we present a case of intestinal NTM infection which developed after allogeneic HSCT. Furthermore, we briefly review the reported cases of intestinal NTM infection developing after HSCT and solid organ transplantation.

\section{Case Report}

A 33-year-old man with unclassified myelodysplastic/ myeloproliferative disease underwent allogeneic bone marrow transplantation from a human leukocyte antigenmatched unrelated donor after being conditioned with total body irradiation (12 Gy) and high-dose cytarabine $(2,400$ $\mathrm{mg} / \mathrm{m}^{2}$ ). Tacrolimus and short-course methotrexate were given for prophylaxis of graft-versus-host disease (GVHD). His post-transplant course was complicated with acute and chronic GVHD (extensive-type) solely involving the skin, both of which were successively treated with long-term prednisolone. Initial dose of prednisolone was $1 \mathrm{mg} / \mathrm{kg}$ for 2 weeks, and the dose was slowly tapered to $0.5 \mathrm{mg} / \mathrm{kg}$ over 2 months. Since day 80 post-transplant, when he had been treated with prednisolone for acute GVHD, he repeatedly

\footnotetext{
${ }^{1}$ Division of Hematology, Department of Medicine, Keio University School of Medicine, Tokyo, ${ }^{2}$ Division of Hematology, Saitama Medical Center, Jichi Medical University, Saitama and ${ }^{3}$ Division of Gastroenterology, Department of Medicine, Keio University School of Medicine, Tokyo

Received for publication December 19, 2009; Accepted for publication February 28, 2010

Correspondence to Dr. Takehiko Mori, tmori@sc.itc.keio.ac.jp
} 
complained of severe abdominal pain and diarrhea with high-grade fever. His white blood cell count was $1.9 \times 10^{9} / \mathrm{L}$ with $71 \%$ of neutrophils and $26 \%$ of lymphocytes, and serum immunoglobulin $\mathrm{G}$ was $635 \mathrm{mg} / \mathrm{dL}$. No significant renal or hepatic dysfunction was observed. Standard bacterial and fungal cultures of blood and stool detected no causative pathogens. Colonoscopy and esophagastroduodenoscopy revealed no significant findings. Double-balloon enteroscopy of the small intestine revealed atrophic villi and mild erosions (Fig. 1). Histological examinations of the small intestine showed marked proliferation of histiocytes without infiltration of inflammatory cells, and Ziel-Nielsen staining detected numerous acid-fast bacilli in the histiocytes (Fig. 2a, b). Acid-fast bacilli found in the stool were negative for a PCR assay specific for Mycobacterium tuberculosis. Based on these findings, a diagnosis of intestinal NTM infection was made, and the combination therapy of clarithromycin (800 mg/day), ethambutol (1,000 mg/day), rifampicin (450 mg/day), and gatifloxacin (400 mg/day) was initiated on day 279 post-transplant. All of the symptoms were completely relieved within 14 days of initiating the therapy. After the 30-day treatment, the therapy was discontinued because of severe toxicoderma, which was treated

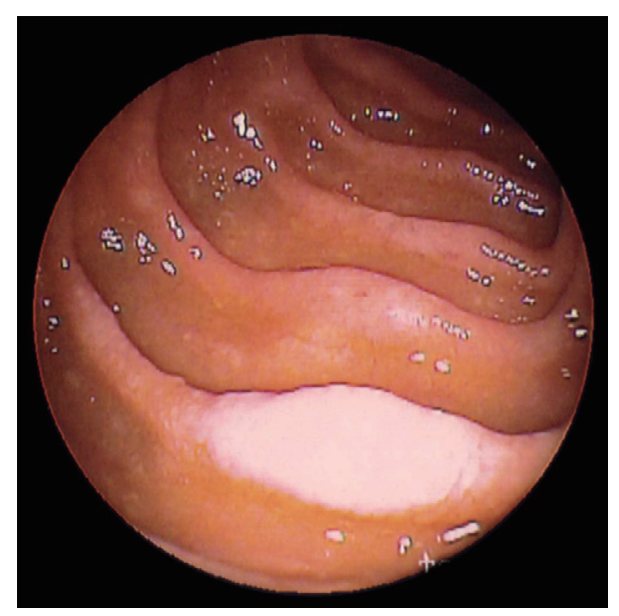

Figure 1. Extensive atrophic villi in the small intestine observed by double-balloon enteroscopy. with high-dose prednisolone $(2 \mathrm{mg} / \mathrm{kg})$. Although the patient was asymptomatic, the culture of the stool continued to grow NTM, and clarithromycin and ethambutol were restarted day 327. The patient died of central line-associated septicemia due to methicillin-resistant Staphylococcus aureus on day 355, and the autopsy showed intestinal NTM infection completely localized in the jejunum.

\section{Discussion}

Although NTM infection after allogeneic HSCT is considered rare, the incidence seems relatively higher than that in the general population (3). An increased incidence of NTM infection has been reported among allogeneic HSCT recipients in recent years, ranging from $0.4 \%$ to $9.7 \%$ of cases (3-7). However, intestinal NTM infection is quite rare, and there has been only one other reported case after allogeneic HSCT (5). In the present case, NTM was completely localized in the small intestine, which made it difficult to make a diagnosis of intestinal NTM. Although doubleballoon enteroscopy led to the diagnosis in our case, the culture for acid-fast bacilli was thoroughly positive. Thus, the culture for acid-fast bacilli of the stool could be a useful, non-invasive method to diagnose intestinal NTM infection.

Impairment of cellular immunity is one of the remarkable immune dysfunctions after allogeneic HSCT. Delayed immune reconstitution could be caused by the administration of systemic glucorticoid, which is verified by the increased incidence of CMV infection in patients receiving glucocorticoid after allogeneic HSCT (8). Thus, long-term administration of systemic glucocorticoid, which was given for persistent GVHD, is considered to have played an important role in the susceptibility of our patient to NTM infection.

Regarding solid organ transplantation, several cases of intestinal NTM infection have been reported. An extensive review of the literature uncovered five cases of intestinal NTM infection after solid organ transplantation (heart 1, liver 1, and kidney 3) (9-13). The characteristics of these cases including the present case and one case after HSCT are described in Table 1. All 7 patients were adults, and in 4 of these, the affected site was the small intestine with or

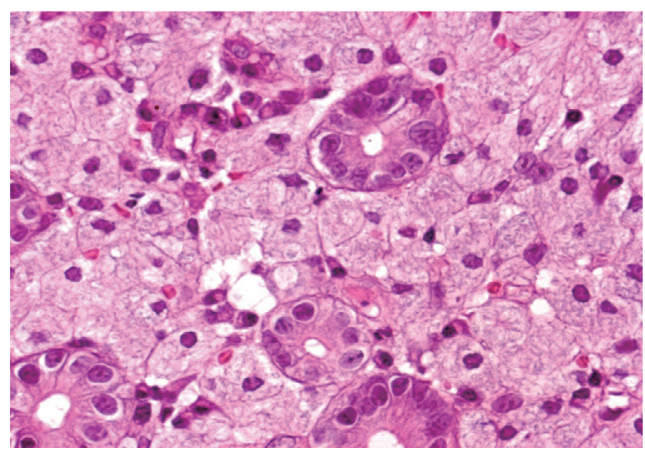

b

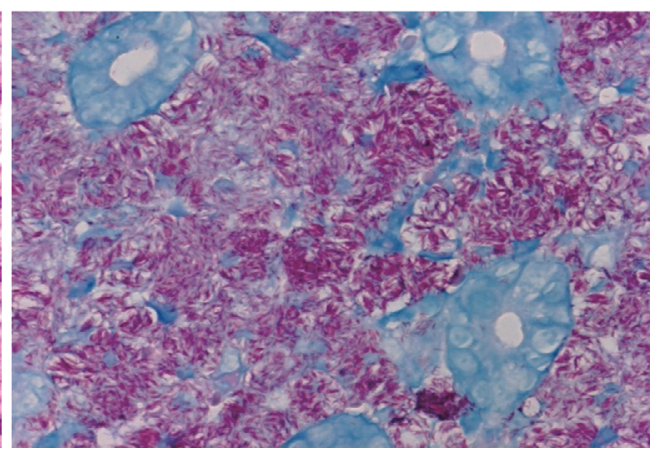

Figure 2. Histological examination of the small intestine (Original magnification $\times 400$ ). a) Hematoxylin and Eosin staining. b) Ziehl-Nielsen staining. 
Table 1. Reported Cases of Intestinal NTM Infection after Solid Organ or Hematopoietic Stem Cell Transplantation

\begin{tabular}{|c|c|c|c|c|c|c|c|c|}
\hline $\begin{array}{c}\text { Reference } \\
\text { No. } \\
\text { (organs) }\end{array}$ & $\begin{array}{c}\text { Age (years) } \\
\text { /Sex }\end{array}$ & $\begin{array}{c}\text { Time from } \\
\text { transplant to } \\
\text { onset }\end{array}$ & $\begin{array}{c}\text { Gastrointestinal } \\
\text { symptoms }\end{array}$ & $\begin{array}{l}\text { Involved } \\
\text { sites }\end{array}$ & NTM species & Treatment & $\begin{array}{c}\text { Response to } \\
\text { treatment }\end{array}$ & Outcome \\
\hline $\begin{array}{c}9 \\
\text { (Kidney) }\end{array}$ & 20/Male & 4 years & Diarrhea & Colon & $\begin{array}{c}\text { Not specified } \\
\text { (Rapid growers) }\end{array}$ & $\begin{array}{l}\text { INH, EB, } \\
\text { SM }\end{array}$ & ineffective & $\begin{array}{l}\text { Died of NTM } \\
\text { infection }\end{array}$ \\
\hline $\begin{array}{c}10 \\
\text { (Kidney) }\end{array}$ & 24/Male & 5 years & $\begin{array}{c}\text { Diarrhea } \\
\text { Bloody stool }\end{array}$ & Colon & $\begin{array}{c}\text { Not specified } \\
\text { (Rapid growers) }\end{array}$ & INH, RFP EB & effective & Died of other cause \\
\hline $\begin{array}{c}11 \\
\text { (Kidney) }\end{array}$ & 35/ Male & 7 months & Abdominal pain & Ileum & M.gordonae & INH, RFP, EB & effective & Alive \\
\hline $\begin{array}{c}12 \\
\text { (Liver) }\end{array}$ & 66/Male & 4 years & Asymptomatic & $\begin{array}{c}\text { Jejunum, } \\
\text { cecum }\end{array}$ & M.gordonae & CPFX, CAM & effective & Died of other cause \\
\hline $\begin{array}{c}13 \\
\text { (Heart) }\end{array}$ & 56/Male & 3 years & Abdominal pain & $\begin{array}{l}\text { Duodenum, } \\
\text { jejunum }\end{array}$ & $\begin{array}{c}\text { M.avium/ } \\
\text { intracellulare }\end{array}$ & $\begin{array}{c}\text { CAM, CPFX, } \\
\text { EB }\end{array}$ & effective & Alive \\
\hline $\begin{array}{c}5 \\
(\mathrm{BM})\end{array}$ & 32/Male & 11 months & Diarrhea & Not specified. & $\begin{array}{c}\text { M.avium/ } \\
\text { intracellulare }\end{array}$ & $\begin{array}{l}\text { CAM, EB } \\
\text { MFLX }\end{array}$ & effective & Died of other cause \\
\hline $\begin{array}{c}\text { Present case } \\
\text { (BM) }\end{array}$ & 32/Male & 3 months & $\begin{array}{c}\text { Diarrhea } \\
\text { Abdominal pain }\end{array}$ & Jejunum & Not specified & $\begin{array}{l}\text { CAM, EB, } \\
\text { RFP, GFLX }\end{array}$ & effective & Died of other cause \\
\hline
\end{tabular}

NTM, non-tuberculous mycobacteria; BM, bone marrow; M, Mycobacterium; INH, isoniazid; EB, ethambutol; SM, streptomycin;

RFP, rifampicin; CPFX, ciprofloxacin; CAM, clarithromycin; MFLX, moxifloxacin; GFLX, gatifloxacin.

without the cecum. The response to combination chemotherapy seems to have been generally effective, although there were variations in the drugs used. The time from transplantation to the onset of intestinal NTM infection was 3 to 5 years after solid organ transplantation with one exceptional case $(7$ months). The time from transplantation to onset in these recipients of solid organ transplantation seems to have been longer than that in the two recipients of HSCT includ- ing our case (3 and 11 months).

We conclude that NTM infection should be recognized as one of the causes of intestinal infection after hematopoietic stem cell or solid organ transplantation, and a culture for acid-fast bacilli should promptly be performed if other causes have been excluded. An accumulation of such cases is required to further elucidate the clinical characteristics and prognosis of intestinal NTM infection.

\section{References}

1. Wagner D, Young LS. Nontuberculous mycobacterial infections: a clinical review. Infection 32: 257-270, 2004.

2. Wallace RJ, Glassroth J, Griffith DE, Olivier KN, Cook JL, Gordin F. Diagnosis and treatment of disease caused by nontuberculous mycobacteria. Am J Respir Crit Care Med 156: s1-s25, 1997.

3. Doucette K, Fishman JA. Nontuberculous mycobacterial infection in hematopoietic stem cell and solid organ transplant recipients. Clin Infect Dis 38: 1428-1439, 2004.

4. Roy V, Weisdorf D. Mycobacterial infections following bone marrow transplantation: a 20 year retrospective review. Bone Marrow Transplant 19: 467-470, 1997.

5. Weinstock DM, Feinstein MB, Sepkowitz KA, Jakubowski A. High rates of infection and colonization by nontuberculous mycobacteria after allogeneic hematopoietic stem cell transplantation. Bone Marrow Transplant 31: 1015-1021, 2003.

6. Unal E, Yen C, Saiman L, et al. Low incidence of nontuberculous mycobacterial infections in pediatric hematopoietic stem cell transplantation recipients. Biol Blood Marrow Transplant 12: 11881197,2006

7. Graviria FM, Garcia PF, Garrido SM, Corey L, Boeckh M. Nontuberculous mycobacterial infections in hematopoietic stem cell transplant recipients: characteristics of respiratory and catheter- related infections. Biol Blood Marrow Transplant 6: 361-369, 2000.

8. Mori T, Okamoto S, Matsuoka S, et al. Risk-adapted pre-emptive therapy for cytomegalovirus disease in patients undergoing allogeneic bone marrow transplantation. Bone Marrow Transplant 25: 765-769, 2000.

9. Kochhar R, Indudhara R, Nagi B, Yadav RVS, Mehta SK. Colonic tuberculosis due to atypical mycobacteria in a renal transplant recipient. Am J Gastroenterol 83: 1435-1436, 1998.

10. Indudhara R, Kochhar R, Mehta SK, Minz M, Chugh KS, Yadav RVS. Acute colitis in renal transplant recipients. Am J Gastroenterol 85: 964-968, 1990.

11. Neuman HB, Andreoni KA, Johnson MW, Fair JH, Gerber DA. Terminal ileitis secondary to Mycobacterium gordonae in a renal transplant recipient. Transplantation 75: 574-575, 2003.

12. Patel R, Roberts GD, Keating MR, Paya CV. Infections due to nontuberculous mycobacteria in kidney, heart, and liver transplant recipients. Clin Infect Dis 19: 263-273, 1994.

13. Munoz RM, Alonso-Pulpon L, Yebra M, Segovia J, Gallego JC, Daza RM. Intestinal involvement by nontuberculous mycobacteria after heart transplantation. Clin Infect Dis 30: 603-605, 2000.

(C) 2010 The Japanese Society of Internal Medicine http://www.naika.or.jp/imindex.html 